\title{
VOLITIONAL EFFORT FORMATION IN SENIOR PRESCHOOL CHILDREN WITH SPEECH IMPAIRMENTS USING VISUAL MODELING
}

DOI: $10.24234 /$ se.2021.3.1.261

\author{
AUTHORS' DATA \\ Olga Piskun, Associate Professor \\ Department of correctional pedagogy and psychology \\ Head of the resource center for supporting students with disabilities \\ Novosibirsk State Pedagogical University, Institute of childhood, Russian Federation \\ Contacts: o-piskun@yandex.ru \\ Olga Shilova, Teacher-speech therapist \\ Head of the district methodological Association of speech therapists \\ Municipal state preschool educational institution of the city of Novosibirsk N 281, Russia Federation \\ Contacts: olya shilova1976@mail.ru
}

\begin{abstract}
The aim of this research is to investigate the process of volitional effort formation in senior preschool children with general speech underdevelopment (GSU) by visual modelling.

The study was conducted using theoretical and practical methods and methods of mathematical statistics. The main indicators of volitional effort formation were determined at the ascertaining stage using methods developed by Smirnova.

Methods were partially adapted for 5-year-old children with GSU, and a map of observations was made. Based on the results of observations of children in experimental and control groups (a total of 38 children), pupils were allocated into four categories according to their behavior in direct educational activities.

At the control stage of the study, (after the special work on volitional effort formation by visual modeling) children in the experimental group demonstrated positive dynamics in volitional regulation. The number of children, achieved a high level in volitional effort formation, has increased, and the number of children with a lower average level has decreased, moreover, none of the pupils remained at a low level.
\end{abstract}


The results of the study showed the effectiveness of the work on volitional effort formation using the method of visual modeling.

Keywords: volitional effort, senior preschool children, visual modeling, formation, method.

\section{INTRODUCTION}

The concept of volitional effort underlies understanding the main mechanisms of volitional regulation. The Volitional effort is necessary in order to include children in learning different activities and hold their attention in the process. The Volitional effort is needed also for planning, committing actions and evaluating achieved results (Iljin, 2011; Ivannikov, 2006; Selivanov, 1992; Kalin,1989).

Preschool children with speech impairments demonstrate underdevelopment of regulatory speech mechanisms and difficulties in concentration and self-control (Smirnova, 1998; Mastukova,1997).

Children with motor alalia may not get involved in the offered activity for a long time (Garkucsha, 2008). The volitional development of children with dysarthria is qualitatively different from the volitional development of children with normal speech (Kireenkova, 2016).

Based on the analysis of provided theoretical data it can be concluded that children with speech disorders experience difficulties in the formation of volitional processes, volitional regulation and volitional qualities.

\section{LITERATURE REVIEW}

The psychology of volition studies specific, inherent only in humans, complex mechanisms of higher mental activity that determine both behavior and personality of an individual as a whole (Iljin, 2011).

According to many researchers, volitional actions are associated with making volition efforts, making decisions and implementing them (Basov, 2007). Volitional regulation is involved in the work of main mental processes (perception, memory, attention, thinking processes, 
imagination, speech), and volitional regulation determines the development of these processes from elementary functions to higher ones (Vigotskij,1982).

In many psychological and pedagogical studies, senior preschool age is characterized as a period of intensive formation of volitional behavior (Gavriluk, 2006). Voluntary actions and volitional regulation determine the intellectual and personal development of preschool children and this is one of the main prerequisites for their readiness for school education (Volkova, 2008; Kravcov \& Kravcova, 2013). Modern studies show that "the psychological readiness of children for school is often characterized by a fairly high level of intellectual readiness and a low level of willpower" (Gavriluk, 2006; Kislickaya, 2007; Sveshnikova, 2010; Sidyacheva, 2006). Underdevelopment of the volitional sphere in preschool children makes it hard for them to study at school, causes some difficulties for teachers in educating such children.

In senior preschool age, the main problems in the mental development of preschoolers become apparent, but before these problems could be attributed to the age norm. One of these problems is speech underdevelopment (Lopatina \& Serebryakova, 1994).

The main issue disclosed in the present study is the insufficient formation of volitional efforts in senior preschool children with general speech underdevelopment. Unformed volitional regulation inhibits correctional and educational processes, reduces their effectiveness, interferes with full-fledged speech activity. Speech is not only a means of communication and cognition, but it is also a regulator of the activity and behavior of children in the early stages of their development (Lubovskij, 1989).

Senior preschool children with speech impairment demonstrate a low level of motivation, self-regulation, volitional attention, memorization, patience, perseverance, determination, courage (Kireenkova, 2016; Pyatnitca \& Bashinskaya, 2011; Mastukova, 1997). The behavior of such kinds of children is impulsive and inconsistent and they show insensitivity to verbal influences of adults (Smirnova, 1992).

Cultural ways of cognition and preservation of accumulated experience play an important role in the development of preschool children. The most significant of these ways fixed by culture is a sign-symbolic means which is especially actively formed in preschool childhood based on children's activities. As it is shown in modern studies, the formation of sign-symbolic activity in correctional and developmental work with children may serve as a means of optimizing general 
mental development in pre-schoolers with developmental problems (Mednikova \& Pekisheva, 2016; Salmina,1988; Sapogova, 1993).

In accordance with ontogenesis, visual modelling is a form of such sign-symbolic activity in preschool childhood (Venger, 1986). Visual modelling matures within the play and productive activities to senior preschool age and this has long been used in teaching practice. Visual modelling is the specific achievement of preschool childhood and a powerful compensatory learning tool in conditions of impaired development (Pyatnitca \& Bashinskaya, 2011; Garcuscha, 2008).

Analysis of modern technologies based on visual models shows their high effectiveness in work with children. Such technologies include information and communication technologies, the theory of the resolution of invention-related tasks, technologies aimed at the development of the cognitive and intellectual sphere and the communication sphere.

The present study detects possibilities of using visual models in conditions of special education for senior pre-schoolers with GSU for the purpose of their strong-willed and, as a consequence, personal development.

\section{METHODOLOGY}

The Experimental study took place in a preschool educational kindergarten in three basic research stages (Table 1).

\section{Participants}

The sample of participants was selected according to an age criterion (senior preschool age) and a type of disorder (the presence of general speech underdevelopment in pupils, confirmed by the conclusion of the territorial psychological, medical and pedagogical commission). The study was conducted in two groups of combined type, experimental and control.

A total of 38 children of senior preschool age with GSU participated in the study. At the time of the experiment, speech disorders in children were partially compensated.

Children with GSU of experimental and control groups demonstrated a similar level of speech development on average at the time of the study.

According to the data of speech diagnostics, at the beginning of the 2018-2019 academic year, in the experimental group, there were 15 children with III level of speech development, three children with II-III level of speech development, and one child with II level of speech development 
who had motor alalia. GSU was complicated by dysarthria in 18 children and by stuttering in 1 child.

At the time of the study, the control group consisted of 16 children with a III level of speech development, two children with II-III level of speech development and one child with II level of speech development. GSU was complicated by dysarthria in all 19 pupils.

Gender differences in experimental and control groups were also minor, in the experimental group there were 12 boys and seven girls, and in the control group, there were 11 boys and eight girls.

\section{Table 1.}

\section{Experimental research stages}

\begin{tabular}{|l|l|l|}
\hline $\begin{array}{c}\text { Experimental } \\
\text { research stages }\end{array}$ & \multicolumn{1}{|c|}{ Work timeline } & \multicolumn{1}{|c|}{ Experimental methods } \\
\hline 1 ascertaining stage & October 2018 & $\begin{array}{l}\text { Ascertaining experiment the study of } \\
\text { psychological, pedagogical and medical } \\
\text { documentation, observation, testing, quantitative } \\
\text { and qualitative analysis of experimental data, } \\
\text { generalization. }\end{array}$ \\
\hline 2 formative stage & December 2018, & $\begin{array}{l}\text { Formative experiment: goal setting, pedagogical } \\
\text { project planning, implementation of the } \\
\text { pedagogical project on the research topic }\end{array}$ \\
\hline 3 control stage & May 2019 2019 & $\begin{array}{l}\text { Control experiment: monitoring of results of the } \\
\text { pedagogical project, generalization and } \\
\text { systematization of control materials, processing } \\
\text { of the results obtained by methods of } \\
\text { mathematical statistics }\end{array}$ \\
\hline
\end{tabular}

\section{Data collection}

At the present moment, there are no specially adapted methods for studying the state of the volitional sphere in preschool children with speech disorders, and, in particular, with general speech underdevelopment. The problem of investigating volitional efforts in pre-schoolers were 
defined in the works of Zaporozjhec (1960,1986), Kotirlo (1971), Neverovich (1986), Cirkun (1991; 2000) presented by Smirnova (2005). The present research is based on the diagnostic tools of Smirnova (2005). She identified the main indicators of voluntary (volitional) behaviour:

- observation of the behavior of children in the process of a direct educational activity (DEA);

- $\quad$ identifying the ability to restrain direct impulsive actions;

- determination of the ability to manage their cognitive processes (perception and attention) in the context of tasks;

- identifying the ability to mediate their actions with a visual example.

These indicators from Smirnova's method were used in this study to identify a level of volitional effort formation in senior preschool children with GSU. The indicators helped to detect the readiness of children to use visual models for regulation of their actions, and this visual modelling was used as the main means of influence in the formative stage of the study. These methods were adopted by researchers with a consideration of the age of pupils and characteristics of their speech development.

Visual material was selected for this study taking into account the limited possibilities of perception and understanding of visual images by children with GSU and their level of speech development according to Levina (2013).

The theme of picture material was chosen to take into account the current lexical topics. The level of tasks difficulty was matched to the recommended diagnostic protocol, used for examining 5-6-years-old children with GSU according to the scheme of Solomaha (2001) and Serebryakova (1999) described in the manual "Diagnostika narushenij rechi u detej i organizaciya logopedicheskoj raboti v usloviyah doshkolnogo obrazovatelnogo uchrezchdenijya".

The children's observation map was compiled during the DEA process according to 2 indicators, activity and discipline. Besides that, protocols of children examination using the methods "Do not peep", "Compare pictures", "Assemble the picture" were made.

Volitional efforts, manifested in behaviour, were identified using children's observation in the DEA process for artistic development (painting) and cognitive development (mathematics and nature-study).

When observing the behaviour of children, two main characteristics were noted: 
1) children's enthusiasm for the DEA theme, which manifested itself in the activity related to DEA theme;

2) compliance with the rules of behaviour, an indicator of this characteristic was discipline in the DEA process.

A quantitative indicator of activity during lessons was a number of initiative actions of children related to the DEA theme (how many times children want to say something by their initiative, raise their hands, ask questions, address teachers or answer teacher questions).

A quantitative indicator of discipline was the number of distractions during the DEA process (distractions were identified as any motor activity and talking unrelated to the DEA theme).

Both indicators were recorded during 20 minutes of DEA. Observations of children's behaviour were made in 5 lessons; after this, average indicators of activity and discipline were calculated for each subject.

Thanks to optimally selected diagnostic tools, it was possible to obtain qualitative and quantitative indicators that were closely related to the research problem when analysing the data.

\section{Data analysis}

The data analysis process consisted of 5 consecutive stages through which numerical answers were received. These numerical answers were reduced to an average value and recorded in research protocols. Thus, protocols contained the results of observations of experimental and control groups during the DEA process (1,2 stages) with consideration of demonstrated initiatives and distractions and the calculation of average values in accordance with certain groups of participants (active/passive, disciplined/undisciplined). According to a number of activities, they were converted into digital units and named accordingly. The $2^{\text {nd }}$ stage is the creation of the research database, systematization of the protocol forms. Columns were compared in nominal units (e.g. "initiative", "distraction") and in a number of respondents, who were coded and numbered.

In the $3^{\text {rd }}$ stage, the average time of restraint of activity (successful completion of tasks) was recorded in both groups, and an average value was calculated.

In the $4^{\text {th }}$ stage, the results of the ascertaining (control) phase of the study have been processed by the method of mathematical statistics. 
The $5^{\text {th }}$ stage is ranking the research data of experimental and control groups at the ascertaining (control) stage, calculating the results using the methods of mathematical statistics. When identifying themes, those key problems were highlighted that were closely related to the research problem.

\section{FINDINGS}

The first ascertaining stage was aimed at diagnosing the initial level of the volitional effort development in 5-years-old pre-schoolers with GSU in two groups, approximately equal in composition and type of speech disorders.

Volitional efforts, expressed in the ability to restrain impulsive movements, were identified by the use of the "Do not peep" technique. Left alone with a child, the experimenter took out a box with a new unknown toy and promised to play an interesting game with him/her. The experimenter asked a child not to pry for some time, while he was preparing material for the game. A quantitative indicator of volitional effort was the time (in seconds) during which children could restrain their impulsive activity. The desire of children for restraint was manifested in their behaviour, namely in their facial expressions, covering their eyes with hands, inventing various actions to help them to sit with closed eyes. The histogram below (Figure 1) demonstrates volitional efforts to restrain impulsive actions in children of experimental and control groups.

\section{Figure 1.}

Distribution of participants in experimental and control groups according to the time of restraint of impulsive actions

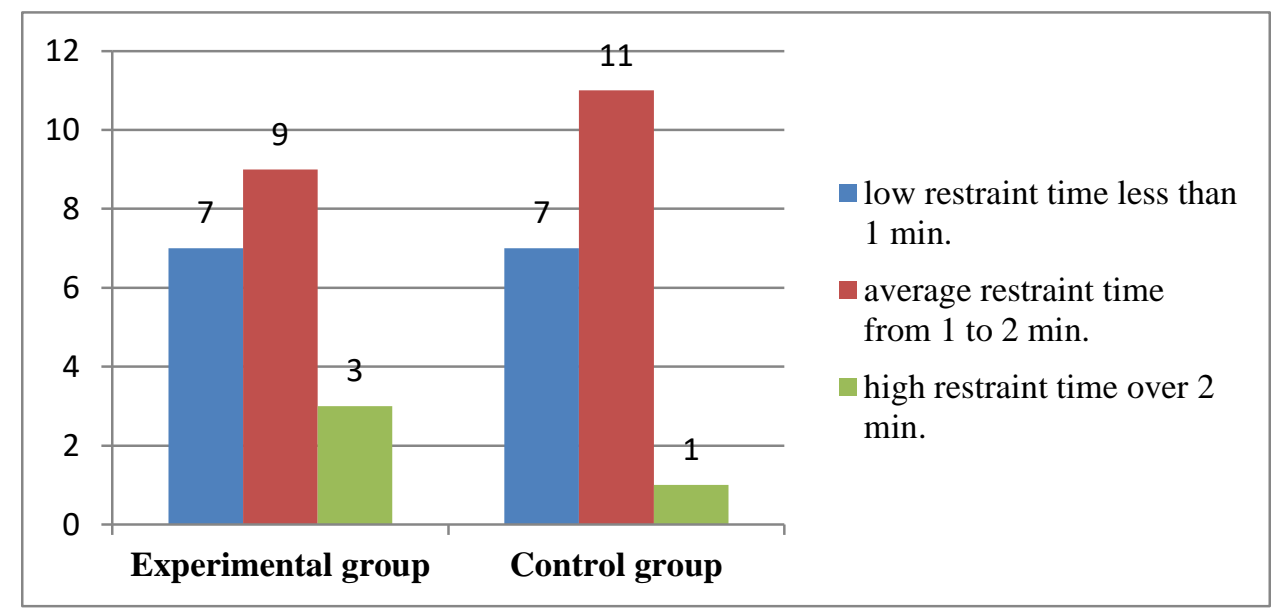


Volitional efforts in the cognitive sphere were tested using the material of the method "Compare pictures". Children were asked to compare two pictures and find 10 implicit differences. In order to detect them, children had to hold their active attention while perceiving them, without being distracted by other actions and other pictures. A quantitative indicator of the successful completion of this task was a number of correctly named differences (out of 10) in two experimental pictures.

Volitional efforts, manifested in the process of action according to a visual model, were revealed with the help of the game "Assemble the picture". A child had to assemble a picture diagonally cut into 6 parts in accordance with the sample. The task was considered unfulfilled if the assembled picture did not match the sample and there were no attempts to correct errors. Results of the ascertaining stage of the study were recorded in protocols. Scores were given for each indicator.

As in the study by Smirnova (2005), all children were divided into 4 groups by their behavior in DEA according to results of observations at the ascertaining stage:

1) active and disciplined children, with high indicators of initiative and a low level of distractions - seven children, accounted for $18 \%$,

2) active and undisciplined children with high indicators of initiative and high and medium levels of distractions - 15 children, $40 \%$,

3) passive and disciplined - eight children, $21 \%$,

4) passive and undisciplined - eight children, $21 \%$.

The data of the ascertaining stage of the study showed, that according to the results of the four methods the lowest indicators of volitional efforts are observed in children demonstrating passivity and indiscipline in DEA. Passive and disciplined children were also among those who did not complete the tasks. Half of the active and undisciplined children also had difficulties. The data of mathematical analysis showed that there were no differences between the two samples in terms of a level of volitional effort formation at the ascertaining stage. Consequently, it can be considered reliable that at the ascertaining stage both groups were statistically equal in terms of a level of volitional effort formation.

The revealed features of the volitional sphere in senior preschool children with GSU may serve as an obstacle to full-fledged speech therapy correction and the implementation of educational activities. Obviously, the identified categories of pupils $\left(2^{\text {nd }}, 3^{\text {rd }}\right.$ and $4^{\text {th }}$ groups) need 
special psychological and pedagogical assistance, as such kind of help contributes to mastering an approximate adapted basic educational program of preschool education.

At the same time, the study showed that most 5-years-old preschool children with GSU have a formed ability to act according to a visual model. The active use of this ability in the correction process may have a positive effect on the development of the volitional sphere in this category of pupils and, as a result, increase its effectiveness.

The formative stage of the study took place in a preschool educational organization. The experiment involved 19 5-years-old children with GSU (experimental group).

Children sequentially mastered three types of actions: substitution, modelling, mental experimentation.

The implementation of the pedagogical project was conducted in three stages:

1. Organizational and preparation stage (October 2018).

2. The main stage is the project implementation (November 2018 - May 2019): the use of visual modelling according to a long-term plan in individual, subgroup and frontal speech therapy classes. The involvement of teachers and parents in the correctional process for volitional effort formation by joint productive activities with children.

3. Final stage (May 2019).

Correctional and developmental work was done in five main areas. Visual modelling was used:

1) in individual-subgroup lessons on formation of sound pronunciation (once a week)

2) in subgroup lessons to improve lexical and grammatical structures and to develop coherent speech (once a week);

3) in lessons on the development of phonemic processes and preparation for learning literacy (once a week);

4) in productive activities with parents (1 - 2 times a month); in independent activity of children through the organization of a developing subject-spatial environment of the group and a speech therapy room (during the entire project).

Modern pedagogical and special speech therapy technologies and methods of visual modelling were used in the process of the project implementation such as speech therapy selfmassage, finger gymnastics, methods of phonemic perception development, methods of formation of phonemic representations and preparation of children with GSU for learning literacy, methods 
of formation of vocabulary and grammatical structures in children with GSU, methods of the development of coherent speech in children with GSU, information and communication technologies, game technologies.

The educational subject-spatial environment was equipped with all materials necessary for the project implementation according to the main areas, i.e. the centres of activities: the centre of individual and subgroup work, the centre of sensorimotor development, the centre of frontal and subgroup work.

Much attention was paid to the equipment of centres with pictures, tables, diagrams, waste material, materials for painting, drawing, modelling designing by sample. Created materials included:

- a card index of manuals on the development of articulatory, mimic and manual motor skills; these are complexes for articulatory, finger, mimic gymnastics, self-massage in pictures and diagrams;

- cards with schemes of articulations for sound correction, albums with labyrinths and cards with pictures and verses for automation of correctly pronounced sounds;

- cards for syllabic word analysis and tokens for sound word analysis;

- a set of stencils for silhouette drawing of subject images on lexical topics was selected;

- a finger pool was equipped with beans, small plastic fruits and vegetables;

- handmade small figures, diagrams and tokens to indicate the main characteristics of sounds;

- picture material was selected and diagrams were made to develop the skills of coherent descriptive and narrative speech;

- $\quad$ sound boxes were made for the development of auditory attention;

- hand-out picture material was selected for all studied sounds;

- demonstrational letters, a magnetic alphabet, a ruler Abacus to form syllable fusion skills were made with the professional help of parents.

A card index of electronic resources was collected:

- presentations for automating sounds in a word,

- demonstrational picture material on lexical topics.

The final stage of the project ended with an open final speech therapy lesson "In Search of the Keys of Knowledge", in which children of the experimental group showed their ability to 
decipher schemes, to follow a plan-scheme, to select and differentiate pictures into sounds similar in pronunciation, to model and recreate letters from fragments, pictures from parts, words from given letters. The behavior of children was distinguished by restraint and discipline. All children successfully coped with the game tasks offered to them, showed initiative, and there was no single case of distraction. An example was the children's project "Alive Letters", one of the stages is shown in Picture 2.

\section{Picture 2.}

\section{Modelling letters of the Alive Alphabet}

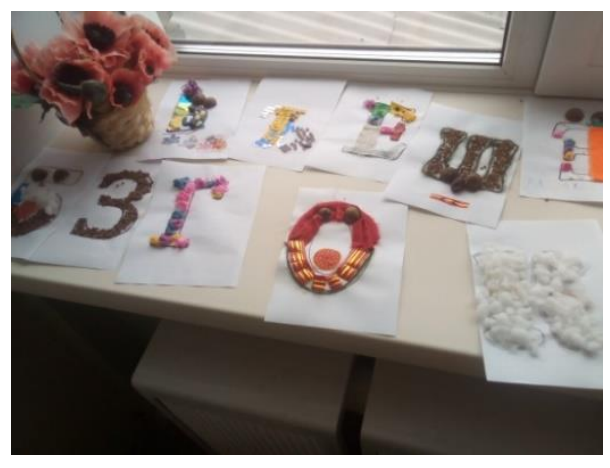

At the control stage of the study, children of the experimental group showed positive dynamics. The number of children who have reached a high level of volitional effort formation has significantly increased (by 26\%), the number of children with a lower average level has decreased (by $10 \%$ ), none of the pupils remained at a low level.

The histogram below (Figure 3) demonstrates quantitative and qualitative changes in the dynamics of volitional effort formation in senior preschoolers with GSU in the experimental group according to the results of all four methods.

\section{Figure 3.}

Dynamics of volitional effort formation in senior preschool children with speech impairments in the experimental group

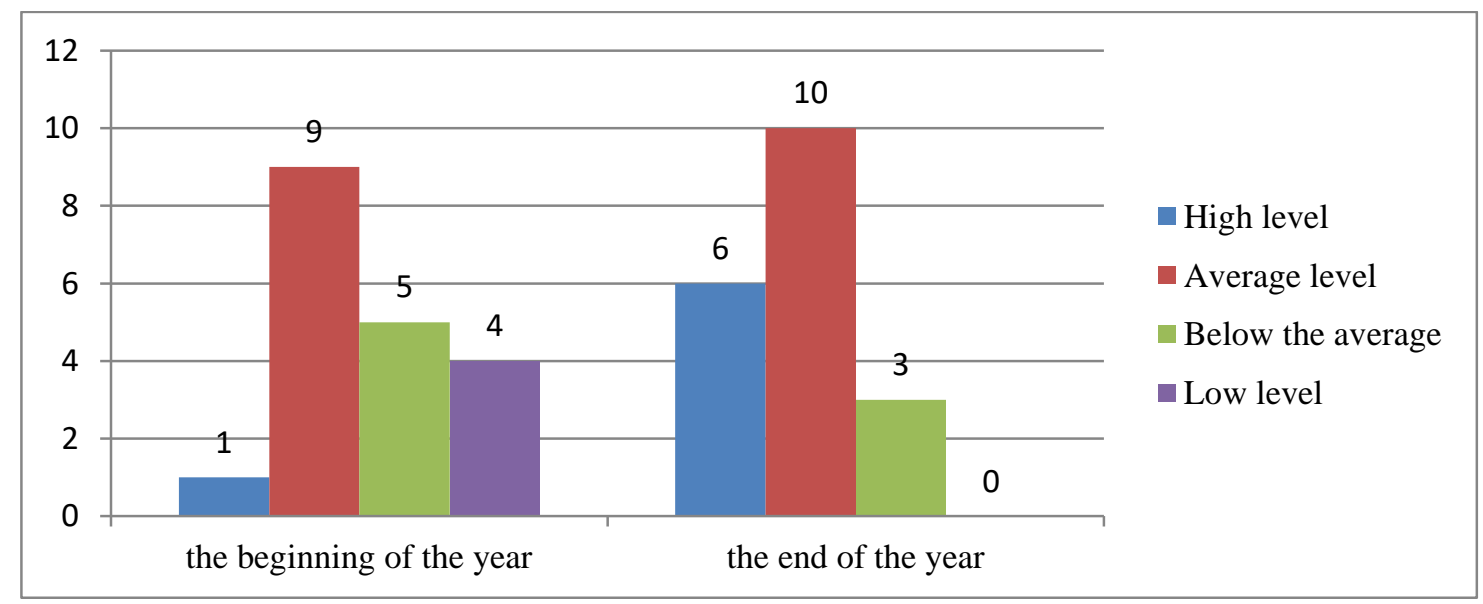


In comparison with children of the control group, qualitative differences are seen in the dynamics of volitional effort formation, i.e. an increase of volitional effort indices in the experimental group occurred due to a rise of the proportion of high indices, while in the control group the dynamics occurred only due to an increase of low indices.

The control stage of the study showed the effectiveness of the work on volitional effort formation by the use of visual modelling, and this is confirmed by the methods of mathematical statistics, namely the Wilcoxon T-test for two dependent samples and the Mann-Whitney U-test.

\section{DISCUSSION}

The aim of this research was to study the process of volitional effort formation in senior preschool children with general speech underdevelopment using visual modelling.

At the present moment, emotional and volitional immaturity is a frequent manifestation of various

forms of dysontogenesis. Most of the children of this category are preschool children with general speech underdevelopment (GSU).

Researchers note that preschool children with speech disorders have difficulties in motivation, self-control, concentration, voluntary memorization, and a weakening of volitional qualities associated with them (Kireenkova 2016; Pyatnitca \& Bashinskaya, 2011; Mastukova, 1997; Selivanov,1992b). The problem of volitional underdevelopment in senior preschool children with GSU is often exacerbated when children enter the school and this is transformed into a problem of psychological readiness for schooling.

Volitional regulation is known to be carried out due to the mediation of higher mental functions by sign systems (Mednikova \& Pekisheva, 2016). One of the correction ways is visual modelling as an additional sign activity that mediates volitional processes.

The present study was based on the assumption that the use of visual modelling in correctional work with senior pre-schoolers with GSU will contribute to volitional effort formation in them as this is a mechanism of volitional regulation of activity. It was assumed that volitional effort formation through visual modelling will have a positive effect on the effectiveness of overcoming GSU in senior preschool children.

To confirm the research hypothesis, the problem of volitional effort formation in senior pre-schoolers with DEA was investigated using theoretical analysis and a practical study. The 
project on volitional efforts formation by visual modelling in senior pre-schoolers with GSU was developed and implemented.

The formative stage of the study took place in a preschool educational institution. The experiment involved 19 5-years-old children with GSU. Correctional and developmental work was done in subgroup and individual speech therapy classes and in conditions of unregulated productive activity with parents. Besides that, conditions for independent activities of children with the use of visual models were created in the group of the preschool educational institution. 5years-old children with GSU mastered three types of actions in sequence:

1) substitution; 2) modelling, 3) mental experimentation (Kravcova, 2011; Kravcova, 2009). The study proved that visual modelling, while included in the correctional and educational process, has a positive effect on the process of volitional effort formation in the activity of preschool children with GSU. Visual modelling also contributes to the formation of volitional regulation of activity and this is manifested in discipline, restraint, the management of cognitive processes. Besides that, visual modelling helps to effectively develop speech skills.

At the end of the academic year pupils of the experimental group successfully participated in the city, regional, nationwide Russian events, festivals, and competitions:

- two pupils became winners with a Winner's diploma (II place) in the Nationwide Russian creative competition for children and teachers "Talantokha - 61", in the nomination "Acting skills", children read poems by their favourite children's authors,

- one pupil took part in the XVI international traditional heuristic project "Day of Defectology. Childhood Ecology of a special child", the girl read a poem from the stage of the NSPU assembly hall (Shilova \& Piskun, 2019a);

- 6 pupils became winners of the open regional festival for children with disabilities "I ask for words" in the nomination "Theatrical creativity". Children performed on the stage of the regional puppet theatre with an excerpt from the play "The Golden Goose".

The project itself became a laureate of the XI city competition of projects "Innovations in Education", in the nomination "Special Child - Equal Opportunities", Department of Education of the Novosibirsk Mayor's Office, City Centre of Education Development, 2019 (Shilova \& Piskun, 2019b).

The implementation of the pedagogical project resulted in the children's project "Alive Letters", in which the pupils of the experimental group participated. Within the framework of the 
project activities, the children were able to demonstrate the skills obtained in a classroom such as skills of volitional regulation of activity, visual modelling, speech planning, forecasting and selfcontrol. As a level of volitional effort formation is a key to the success of children when they enter school, the importance of the findings of the research is proven by the relevance to the problem under study.

\section{LIMITATION OF THE STUDY}

To a less degree, the use of visual modelling affects the development of motivational components of will such as activity and initiative. This is evidenced by the low dynamics of indicators of volitional effort formation in children with low activity and in passive undisciplined children. For the development of these components of will in these categories of pupils, along with the use of the method of visual modelling, it is necessary to use the following methods for a long period of time:

- the use of a team approach of all specialists and teachers of preschool educational organizations in psychological and pedagogical assistance in relation to children and their families;

- constant monitoring of the dynamics of special educational needs in children in these groups due to their psychophysical state of health and the interaction of specialists in psychological and pedagogical support with medical specialists and parents (legal representatives);

- expanding the range of applied methods and techniques influencing volitional sphere formation,

- longer periods of psychological and pedagogical correction.

Noncompliance with the above-mentioned conditions results in negative dynamics of the development of volitional efforts.

\section{IMPLICATIONS FOR PRACTICE AND FUTURE RESEARCH}

This study revealed and once again emphasized the importance of volitional effort formation in children with speech disorders. Research work in this direction should not be limited 
to only one type of disorder, this is relevant for all senior preschool children, both who have health problems and who normally developing. It can be assumed that the study will help educational organizations, social protection, health care, public organizations in their work with children.

\section{CONCLUSION}

The present study examines the psychological and pedagogical effectiveness of the use of the visual modeling method in volitional effort formation in senior preschool children with speech impairments. The results of the study highlight the importance of this area in assisting children with health problems. The identification of a low level of volitional effort formation shows the need for targeted and systematic measures aimed at overcoming this disadvantage in children with disabilities because this will help them in the transition to school.

\section{REFERENCE LIST}

1. Basov, M., Y. (2007). Volya kak predmet funkcionalnoj psychologii. Metodika psichologicheskih nabludenij za detmi. Saint-Petersburg: Aletejya.

2. Diagnostika narushenij rechi u detej i organizaciya logopedicheskoj raboti v usloviyah doshkolnogo obrazovatelnogo uchrezchdenijya (2001) Saint-Petersburg: Detstvo-Press

3. Gavriluk, N., P. (2006). Formirovanije volevih kachestv mladshego shkolnika kak uslovije ego razvitijya I uspeshnosti $\mathrm{V}$ obuchenii. Saint-Petersburg SPB: from http://www.dissercat.com/content/formirovanie-volevykh-kachestv-mladshegoshkolnika-kak-uslovie-ego-razvitiya-i-uspeshnosti-v\#ixzz4zUyU9jCb

4. Garkucsha, U., F. (Red.). (2008). Korreccionno-pedagogicheskaya rabota v doshkolnih uchrezchdeniyah dlya detej bs narusheniyami rechi Moscva: Sekacshev V.U. TC Sfera, NII Shkolnih tehnologij.

5. Ivannikov, V., A. (2006). Psichologicheskije mehanizmi volevoj regulyacii. SaintPetersburg: Piter.

6. Iljin, E.P. (2011). Psichologiya voli Saint-Petersburg: Piter.

7. Kalin, V., K. (1989). Volevajya regulyaciya deyatelnosti. Tbilisi 
8. Kireenkova, S., L. (2016). Osobennosti volevoj sferi u detej s dizartriej. Molodoj uchenij, 5, 690 - 692, from https://moluch.ru/archive/109/26569/

9. Kislickaya, L., A. (2007). Lichnostnoje razvitije pervoklassnikov, psichologicheski gotovih $\mathrm{I}$ ne gotovih $\mathrm{k}$ shkolnomu obucheniju Moscva from http://www.dissercat.com/content/lichnostnoe-razvitie-pervoklassnikovpsikhologicheski-gotovykh-i-ne-gotovykh-k-shkolnomu-obu\#ixzz4zVAFN73P

10. Kravcova, K., A. (2011). Psihologicheskie uslovijya formirovanijya sposobnosti starschego doschkolnika $\mathrm{k}$ naglyadnomu modelirovaniju. Samara. from http://www.dissercat.com/content/psikhologicheskie-usloviya-formirovaniyasposobnosti-starshego-doshkolnika-k-naglyadnomu-mod\#ixzz4zUqC3OuN.

11. Kravcov, G., G., \& Kravcov,a E.,E. (2013). Psichologiya I pedagogika obucheniya doshkolnikov. Moscva: Mozaika-Sintez.

12. Kravcova, K., N. (2009). Teoretiko-metodologicheskie osnovi razvitiya sposobnosti starshego doshkolnika k naglyadnomu modelirovaniju. Vestnik KGU iv. N.A.Nekrasova, Tom $15,132-134$.

13. Levina, R., E. (Red.), (2013). Osnovi teorii I practiki logopedii. Moscva: Aljyans.

14. Lopatina, L., V., \& Serebryakova N., V. (1994). Logopedicheskaya rabota v gruppah doshkolnikov so stertoj formoj dizartrii. Saint-Petersburg: Obrazovanie.

15. Lubovskij, V., I. (1989). Psychologicheskie problemi diagnostiki anomalnogo razvitiya detej. Moscva: Pedagogika.

16. Mastukova, E., M. (1997). Lechebnaya pedagogika (rannij I doshkolnij vozrast): Soveti pedagogam I roditelyam po podgotovke $\mathrm{k}$ obucheniu detej s osobimi problemami v razvitii. Moscva: VLADOS.

17. Mednikova, L., S., \& Pekisheva, E., V. (2016). Ontogenez znakovo-simvolicheskoj deyatelnosti: ot teoreticheskogo analiza problem $\mathrm{k}$ practice formirovaniya semioticheskoj funkcii soznaniya detej s problemami v razvitii. Defectologiya,6, $42-53$.

18. Pyatnica, T., V., \& Bashinskaya, T., V. (Red.). (2011). Sistema korrekcionnogo vozdejstviya pri motornoj alalii. Moscva: Sfera.

19. Salmina, N.G. (1988). Znak I simvol v obuchenii. Moscva: Izd-vo Mosc. Un-ta.

20. Sapogova, E., E. (1993). Rebenok I znak: Psychologicheskij analiz znakovosimvolicheskoj deyatelnosti doshkolnika. Tula. Priok. Kn. Izd-vo. 
21. Selivanov, V., I. (1992). Volevaya regulyaciya I aktivnost lichnosti, Psychologicheskij zjurnal, 4, 14 - 25.

22. Selivanov, V., I. (1992). Izbrannie psychologicheskie proizvedeniya (Volya, ee razvitie I vospitanie). Ryazan. RGPISidyacheva, N., V. (2006) Emocionalno-volevoj component $\begin{array}{llll}\text { gotovnosti } & \text { doshkolnika } & \mathrm{k} & \text { Moskva }\end{array}$ from http://www.dissercat.com/content/osobennosti-formirovaniya-volevykh-kachestvmladshikh-shkolnikov-razlichnykh-sistem-obucheni\#ixzz4zUxlCq9S

23. Shilova, O., V., \& Piskun O.,U. (2019a). Puti formirovaniya volevih usilij kak osnovnogo mehanizma volevoj regulyacii u starshih doshkolnikov s ONR posredstvom naglyadnogo modelirovaniya. Sovremennie napravleniya psychologo-pedagogicsheskogo soprovojzdeniya detstva (str.304 - 306). Novosibirsk: NGPU from /views/sbo/36945/read.php

24. Shilova, O., V., \& Piskun O., U. (Sost.). (2019b). Konkursi schtecov kak sposob organizacii hudojzestvenno-rechevoj deyatelnosti s doshkolnikami v processe kompensacii rechevih narushenij. Ecologiya detstva osobogo rebenka. Novosibirsk: NGPU, In-t otcritogo distancionnogo obrazovaniya. - $2,76 \quad \mathrm{~Gb}$; from https://lib.nspu.ru/views/library/83985/web.php _ - ISBN 978-5-00104-456-7 Email:office@iode.nspu.ru http://iode.nspu.ru

25. Smirnova, E., O. (2005). Diagnostika psychicheskogo razvitiya detej ot rojdeniya do 3 let: Metodicheskoe posobie dlya prakticheskih psychologov. Saint-Petersburg: DETSTVOPRESS.

26. Smirnova, E., O. (1998). Razvitie voli I proizvolnosti v rannem I doshkolnom vozrasta. Moscva: Institut prakticheskoj psychologii - Voronejz NPO «MODEK».

27. Smirnova, E., O. (1992). Usloviya I predposilki proizvolnogo povedeniya v rannem I doshkolnom detstve. Moscva. Moscovskij gosudarstvennij universitet im. M.V. Lomonosova.

28. Sveshnikova, E., M. (2010). Osobennosti formirovaniya volevih kachestv mladshih shkolnikov razlichnih system obucheniya. Nijchnevartovsk. from http://www.dissercat.com/content/osobennosti-formirovaniya-volevykh-kachestvmladshikh-shkolnikov-razlichnykh-sistem-obucheni\#ixzz4zUxlCq9S 
29. Venger, L., A. (Red.). (1986). Razvitie poznavatelnih sposobnostej v processe doshkolnogo vospitaniya. Moscva: Pedagogika.

30. Vigotskij, L., S. (1982). Voprosi detskoj (vozrastnoj) psychologii (T.4., sobranije sochinenij). Moskva: Pedagogika

31. Volkova, O., V. (2008). Specifika razvitijya komponentov volevogo dejstvijya starchih dochkolnikov, otnosyaschihsya $\mathrm{k}$ kategorii chaste boleushih detej. Molodoj uchenij,1,2008; from https://moluch.ru/archive/1/23/ 